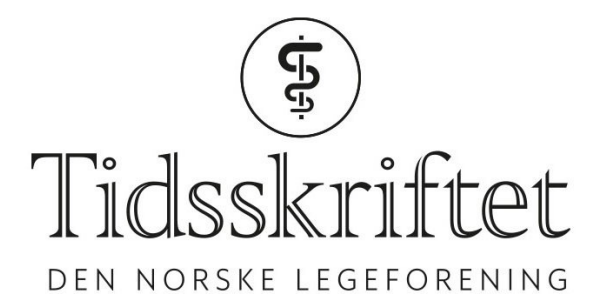

DEN NORSKE LEGEFORENING

\title{
Hissige diskusjoner i doktorklubben
}

LEGELIVET

\section{KARL O. NAKKEN}

E-post: karln@ous-hf.no

Karl O. Nakken er pensjonert nevrolog. Han har i over 35 år vært ansatt ved Spesialsykehuset for epilepsi (SSE) i Sandvika.

Av og til går diskusjonens bølger høyt i doktorklubben. Tonen er hissig og frontene steile. Men vi er alle enige om én ting: For å bli en god kliniker må man være et godt menneske.

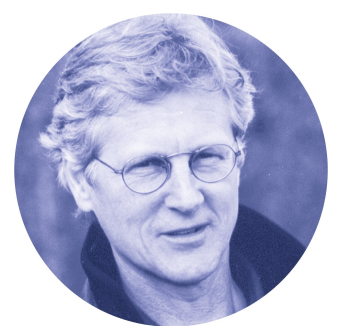

Foto: privat

Det blir stadig vanskeligere å finne en møtedato som passer for alle doktorklubbens medlemmer. Halvparten har nemlig skaffet seg «hytte» i Sør-Europa og er stadig på reisefot. Vi andre som er tro mot gamlelandet, løfter nødig vår moralske pekefinger. Vi vil ikke virke fordømmende. Langt mindre harselerende. Det er ikke i vår natur. Likevel kan vi kanskje ha kommet til å antyde at vi synes de er noen pysete klimaflyktninger som ikke lenger tåler noen få blå grader. Og at de ikke eier flyskam. Og som et medlem helt riktig påpekte: Folk som flyr ofte, mister lett bakkekontakten.

Da vi gikk på doktorskolen i Oslo i årene 1965-71 var kvinneandelen på kullet vårt under 20 \%. I dag er den rundt 70 \%. Det synes vi er betenkelig. Vi har naturligvis ikke noe imot kvinner. Tvert om. Men vi tror arbeidsmiljøet vårt er tjent med en jevn kjønnsfordeling. Av og til oppstår sågar søt musikk. Et medlem var rask til å innskyte at den musikken nok kan diskuteres. Han hadde en periode hatt en kvinnelig sjef som han bestemt mente hadde utviklet sterke følelser for ham - et intenst hat.

I doktorklubben er vi enige om at fastlegene bør over på fast lønn. Det ligger jo i selve ordet. Alle er vi bekymret for den økende byråkratiseringen av helsevesenet, særlig i sykehussektoren. Med mye meningsløs rapportering, som vitner om en grunnleggende mistillit til oss leger, har vi fått stadig mindre tid til pasientarbeid. Det tærer på humør og motivasjon. Dette problemet mener vi lett lar seg løse: Hele sjiktet av mellomledere fjernes, noe som effektivt ville satt en stopper for det vi ikke nøler med å kalle en bullshitifisering av sykehussektoren.

På siste møte i doktorklubben spurte jeg medlemmene om de leste Tidsskriftet, og i tilfelle 
hva de leste. Jo, alle leste Tidsskriftet, og som én la til, i hvert fall nekrologene. Det ledet oss inn på døden. Det kom frem at enkelte hadde noen vage forhåpninger om at døden ikke var siste stopp. Jeg minnet da om min åndsbror Peter Wessel Zapffe. Han var grunnleggende pessimistisk og mente døden kom som en befrielse fra det han kalte livssmerten - en smerte folk flest søkte å lindre gjennom fotballkamper, lykkepiller, alkohol eller religion. Selv fant han en viss trøst i humor og fjellklatring. Han mente menneskearten var en tragisk skapning og at tilværelsen i bunn og grunn var meningsløs og urettferdig.

Jeg refererte også til Hans Børli som et sted sier at kanskje er sannheten om døden jernhard og stutt: Slutt. Et av våre medlemmer var redd at han etter døden nok var glemt allerede etter 14 dager. Vi andre mente hans anslag var vel optimistisk.

Jeg opplever at det av og til kan være vanskelig å slippe til med mine bunnsolide argumenter. Da finner jeg trøst i at vi som er tause, i hvert fall har våre ord i behold

Ofte diskuterer vi helsepolitikk. Enkelte ganger også partipolitikk. Mellom medlemmene er det åpenbart et stort spenn i synet på hvordan samfunnet og særlig helsevesenet bør organiseres. Selv om vi i teorien er enige om at vi må ha respekt og toleranse for våre meningsmotstandere, virker enkelte av medlemmene helt uforsonlige i sin omtale av partier de selv ikke stemmer på. Her er de nådeløse: Folk i FrP er kyniske, vulgære og fremmedfiendtlige egoister som mest av alt minner om Odd Børretzens måker: skal ha, skal ha. Folk i Høyre er kapitalister som med sin privatiserings- og kommersialiseringsiver legger veien åpen for et todelt helsevesen. Folk i Senterpartiet er en gjeng bygdetullinger, mens folk i Venstre er kronisk ambivalente. Folk i KrF er dogmatikere fra bibelbeltet på SørVestlandet som nekter å innse at landet er i ferd med å avkristnes. Folk i Ap, selve ørnen i norsk politikk, kjemper for tiden om å gjenvinne makten, men ingen vet hva partiet skal bruke den til. Folk i MDG er salatfantaster og miljøterrorister, folk i SV er akademiske salongradikalere, og folk i Rødt er en gjeng antikapitalister med rabulistisk tankegods. Diskusjonene bærer ofte preg av uforsonlighet.

I slike diskusjoner er noen medlemmer mer høyrøstede og intense enn andre. Jeg opplever at det av og til kan være vanskelig å slippe til med mine bunnsolide argumenter. Da finner jeg trøst i at vi som er tause, i hvert fall har våre ord i behold.

Et annet medlem fortalte at han for en tid siden fikk en av sine ungdoms forelskelser på kontoret. Han mente det hadde vært et hyggelig gjensyn, og etter konsultasjonen hjalp han henne på med kåpen. Da var det at hun kom med et hjertesukk om at tidene nok hadde forandret seg. Hun kunne huske en tid da han ivret etter å få av henne klærne, mens det nå gjaldt å få dem på ...

Publisert: 9. september 2019. Tidsskr Nor Legeforen. DOI: 10.4045/tidsskr.19.0405

(C) Tidsskrift for Den norske legeforening 2020. Lastet ned fra tidsskriftet.no 